\title{
TMT social capital, network position and innovation: the nature of micro-macro links

\author{
Guoyang Zheng ${ }^{1}$, Li Zhu ${ }^{2 *}$, Chao Liu' ${ }^{1}$ and Yu Chen ${ }^{2}$
}

\author{
* Correspondence: paperlizhu@nsd. \\ pku.edu.cn \\ ${ }^{2}$ National School of Development, \\ Peking University, Beijing, China \\ Full list of author information is \\ available at the end of the article
}

\begin{abstract}
Employing a sample of 1476 firms and 5130 firm-years in China, we examine the relationship between social capital and macro organizational innovation. Based on the relational view and social capital theory, this study investigates how the top management team (TMT) inside an organization bridges and bonds social capital to influence innovations combined with organizational network position. Through empirical tests based on listed companies in the whole network of the interlocking directorate using the dataset of listed companies in China from 2008 to 2014, the study finds that: (1) TMT global social capital has an essential positive effect on innovation, (2) TMT overseas social capital has significant positive consequences on prestige and power (network position), (3) network position mediates the relationship between TMT overseas social capital and innovation, and (4) TMT bank social capital has a moderating effect on the relationship between network position and innovation.
\end{abstract}

Keywords: Top management team (TMT), Power, Prestige, Network position, Innovation

\section{Introduction}

In the era of innovation, creative or innovative capability is the vital asset or potential capacity of a firm (Huang 2011). Innovation requires a great deal of resource input; social capital may influence this process through innovation diffusion (Abrahamson and Rosenkopf 1997; Cho et al. 2012), collaboration networks (Ahuja 2000), and trust. In the period of the transition economy in China, firms may embody more significant social capital to compensate for the lack of market-supporting institutions (Peng and Heath 1996). Given the uncertainties in the reform stage (Walder 1989, 1991; Keister and Lu 2001), firms seek help from informal institutions to support organizational goal achievement. As one extension of the resource-based viewpoint, the relationship-based view maintains that competitive advantages not only come from resources of firms but also from embedded networks and dyadic relationships (Lane and Lubatkin 1998; Dyer and Singh 1998).

"Social capital appears to be the bedrock of innovative capabilities" (Subramaniam and Youndt 2005: p. 495). Social capital theory assumes that internal and external networking relationships provide both value to actors and access to resources embedded in external linkages (Li et al. 2014). Peng and Luo (2000) have demonstrated the social context, in which ingrained managerial ties are extremely critical. Top management 
team (TMT) may also cultivate interpersonal relations and connections with actors in other firms or government officials ( $\mathrm{Li}$ et al. 2014) via work experience. TMT's social capital may include a set of assets contained in relationships (Lin et al. 2001). Corporate network relationships and social capital will be influenced by the TMT members. At the same time, the basis for the performance of the executives is the social capital they are able to utilize (Zhou et al. 2010).

Existing research on the relationship between board interlocks and corporation innovation mainly focuses on the positive effects of board interlocks on patenting and R\&D spending (Helmers et al. 2017), new product introduction (Srinivasan et al. 2018), inventive capabilities (Sullivan and Tang 2013) and so on. Existing research examines the ways in which the social capital of the TMT affects the company's innovation such as through information exchange, knowledge sharing and technology transfer (Lawson et al. 2008), and increases the efficiency of information flow across organizations (Ward and Feldman 2008), but has not paid attention to the impact of the micro TMT social capital on the macro corporate social capital and the indirect effects on corporate innovation. Companies, like other actors in society, are embedded in the network of economic and social relations (Uzzi 1996; Granovetter 1985). Our approach is consistent with TMT social capital, and also in line with the viewpoint of firms involved in social networks together with other actors (Granovetter 1985; Uzzi 1996; Burt 2009; Gulati et al. 2000; Rowley et al. 2000). A firm's network, which provides exceptional access to capabilities and resources outside the organization (e.g., capital, service, goods, and innovations), can be seen as the resource in itself (Andersson et al. 2002). The assets obtained through this network are relatively irreplaceable and inimitable (Gulati 1999; Gulati et al. 2000) for the path-dependent process is idiosyncratic and difficult to imitate. The specific situation provides a fascinating context through which we can explore the relationship between micro and macro links (Luo and Chen 1997; Peng 2000).

As an extension of resource-based theory, which shows that the quality and quantity of resource is unevenly distributed (Barney 1991), we enlarge the boundary of resource acquisition to the embedded social networks (Inkpen and Tsang 2005). As another extension of innovation related to dynamic theory proposed by Nonaka (2000: p. 25), we extend "input-process-output" and "how efficiently it can deal with information and decisions in an uncertain environment" to a relational view by linking micro-macro aspects together. Overall, based on research by Peng and Heath (1996), Luo and Chen (1997), and Peng (2000), and using quantitative data to analyze the benefit in economic transitions, the extended efforts of our study combine micro TMT social capital (overseas social capital and bank social capital) and macro organizational network position (prestige and power). Thus, this study focuses on the following two questions: (1) "what flows across the links" (Stinchcombe 1990: p. 381), and (2) the mechanism of micro TMT social capital transformed into macro corporate social capital and their combined effect on organizational innovation, based on recent calls for more attention to influence at the organizational level (Finkelstein et al. 2009).

Based on 5130 listed firms' networks constructed by interlocking directors in China, this study attempts to reveal the transformation from micro social capital to macro social capital and their joint effects on enterprise innovation. Additionally, it explores the activation mechanism of senior executives' overseas capital in the process of innovation 
and provides beneficial theoretical enlightenment as well as practical suggestions for improving innovation ability through social capital.

\section{Theoretical background and hypotheses \\ Micro and macro social capital}

Research on management issues from the perspective of social networks emerges in large numbers from the 1970s, although the definition of social capital has changed (Bourdieu 1986; Coleman 1990; Putnam 1993; Lin 2008). Some researchers believe social capital is individual property (Portes 1998), while some researchers argue it is the property of individuals and their social relations (Coleman 1990); other researchers think social capital belongs to the group (Bourdieu and Wacquant 1992). Still others hold the view that it belongs to groups, political groups, communities and nations (Putnam et al. 1993).

Researchers in the fields of social capital and social networks have pointed out that resources can be obtained through social networks, which are embedded in the interrelated networks of individuals, groups, and nations (Bolino and Turnley 2002; Inkpen and Tsang 2005). In other words, people access tangible and intangible resources at the individual, group and organizational levels through social interaction and connection with others. From resource-based theory, social network theory indicates that enterprises can obtain better internal and external resources through the construction and management of network relationships. The ability to develop and manage network relationships between organizations has become a core competence of an enterprise because resources are of great importance to business and innovation success (Leibold et al. 2007).

\section{TMT social capital}

According to Upper Echelons research, "relations of the value and cognitive bases of powerful actors in the organizations" may explain organizational results (Hambrick and Mason 1984: p.193). As an extension of Upper Echelons-based view, social capital refers to the outcomes of networking relationships that can be described as internal characteristics within a group, such as connection, norms, trust, and cooperation for universal benefit (Tsai and Ghoshal 1998). Previous researchers demonstrate two primary dimensions with respect to highest level external relationships; the former is links with business managers of other firms inside or outside the industry (Geletkanycz and Hambrick 1997), while the latter lies in financial institutions, officials and political institutes (Peng and Luo 2000).

Geletkanycz and Hambrick (1997) have shown that different aspects of a top manager's connections in business networks cause different benefits (such as resource or information), which may lead to various outcomes in innovation (Paananen 2009) and ambidextrous innovations management ( $\mathrm{Li}$ et al. 2014). The social networks of the TMT's social capital can be considered as a set of assets contained in relationships (Lin et al. 2001). Nahapiet and Ghoshal (2000) have also developed a framework to demonstrate the effects of social capital on the transfer process of explicit knowledge, tacit knowledge and new intellectual capital generation (Nahapiet and Ghoshal 2000). Based on the former research, we examine the TMT characteristics such as functional 
background (Shipilov and Danis 2006), educational or tenure backgrounds, interactions, diversification and demography (Hambrick and D'Aveni 1992; Michel and Hambrick 1992; Johnson and Phyllis 1998; Smith et al. 1994; Shipilov and Danis 2006). We focus on the TMT overseas and bank social capital to represent the micro social capital in this research.

\section{Organizational network position}

A firm's network position, especially when central and advantageous, may influence the actor's innovation by accessing different knowledge, and recognizing and responding to market opportunities (Tsai 2001). Different network position represents different capability and opportunity for an actor's access to new knowledge, which is necessary to generate new products and innovative ideas. Prestige, power and wealth are different social resources in the field of social stratification research (Lin 2002), and there is an independent relationship between prestige and power (Jianwen and Yandong 2011). This study defines prestige and power from the perspective of the macroscopic enterprise level rather than micro individual level, and at the same time, identifies them as essential elements obtained by an enterprise in the social network due to its network position. In a general sense, prestige is a symbol of personal status, which refers to the recognition and evaluation that individuals receive in society (Ling 2009). According to social stratification studies, the distribution of prestige will be significantly affected by the individual differences in class, occupation, and status. In other words, a person will have greater influence when his network position is better. In existing research, scholars use centrality to measure the prestige of an enterprise; so similar to the study at the individual level, an increase in the level of prestige depends on the corporate network position.

Social capital theory emphasizes that social networks and the resources brought by the system lead to the variances in power position among individuals and organizations in society. As a result, different patterns of power distribution have been formed (Putnam 1995). Over time, the network will be dominated by core enterprises that have distinct advantages, and the network control power is the structural power given by the network position (Powell et al. 2005). Therefore, we conclude that the control power of an enterprise over others depends on its network position. Even though generated by social recognition, prestige is not necessarily linked with social resources, with which power is more closely connected. However, higher-prestige enterprises will be trusted in maintaining network and more willing to cooperate than others.

\section{TMT overseas social capital and innovation}

The role of social capital in innovation is a relatively new topic, and most relevant research and empirical studies show that social capital is positively related to organizational innovation (Landry et al. 2002). Thus, the social capital of the top management group is significant to business innovation since executives are crucial in business operations. Executives have two kinds of social capital: Internal social capital which means executives share values among team members, and external social capital which is a bridge connecting to other members and organizations. Existing studies demonstrate that corporate social capital not only enables a firm to access 
heterogeneous information and resources, but may also facilitates the establishment of behavioral norms, communication models and mutual-trust platforms with stakeholders inside a social network. As a result, corporate social capital has the potential to boost business model innovation (Jing et al. 2014). Different dimensions of social networks exert a positive impact on enterprise growth (Qian et al. 2010).

Recently, executives with overseas backgrounds have gradually attracted the attention of business and academics. According to Upper Echelons Theory, executives' experiences, values, and personalities greatly influence their interpretations of confronted situations and, in turn, affect their choices (Hambrick 2007). So, it makes sense to give attention to how executives influence entire TMT and the enterprise when conducting a study on TMT value creation. Executives with overseas experiences have experienced professional backgrounds and international horizons, and meanwhile, they play a leading role in industrial and technological progress (de la Tour et al. 2011). They are exposed to cutting-edge global technologies and familiar with the future direction of development and innovation. At the same time, they have built strong or weak ties with international talents. So, we use executives' overseas working experiences to measure TMT overseas social capital (Jokinen et al. 2008).

As a kind of external social capital, overseas social capital of a TMT supports the enterprise in two ways. To begin with, executives with overseas work experiences will bring different cognitive resources and information to TMTs and enterprises through their connections with foreign enterprises. Within the TMT, this cognitive and knowledge diversity will improve TMT decision-making quality (Wei and Wang 2002) and subsequently optimize corporate innovation decisions and performance. In other words, the injection of overseas capital via the executives' overseas network increases the effectiveness of the executive team to some extent. What's more, overseas social capital of executives can provide a technical resource for enterprises, including information transfer and advanced technology introduction via network ties. Innovation is highly dependent on knowledge (Savory 2009), so corporations have relatively high requirements of internal technology knowledge. Thus, executives with overseas backgrounds are competing due to their high professional level and heterogeneous resources obtained via the network.

In summary, executives with overseas backgrounds not only provide the enterprise with the appropriate knowledge and technical support but also offer specific directional guidance for innovation and deliver innovative signals. In the two ways expressed above, overseas social capital plays a role in innovation and promotes the improvement of creative ability. From theoretical and empirical research mentioned earlier, we propose the following:

Hypothesis 1: There is a positive relationship between TMT overseas social capital and innovation.

\section{TMT overseas social capital and network position}

Some studies show that education and income are two crucial factors that determine the prestige position of an individual. Compared to the impact of income, the influence of education on prestige is more considerable in the Chinese situation (Li 2005). In 
other words, the professional groups with knowledge capital have greater prestige. It is the same for the executives with overseas working experience, since they have more information and knowledge in the related field and a broader field of vision.

According to Social Network theory, information will boom and flourish via ties between enterprises (Burt 2009). Hiring executives with global backgrounds will create a significant effect as they spread unique information conveyed by enterprise-specific behavior through networks. Enterprises gain prestige by engaging stakeholders through reputation and fame of employees with overseas backgrounds. The prestige of an enterprise influences stakeholders' judgment of it; therefore, the greater prestige an enterprise maintains, the more support and communication it obtains (Levin et al. 1985), and the easier it will be to have legal status in the market or legitimacy from stakeholders. Thus, an enterprise can obtain prestige and legitimacy from stakeholders due to executives' high professional reputation from their overseas backgrounds, and provide favorable conditions for further network prestige. To sum up, executives' overseas social capital has a transmission effect on corporate social capital, bringing higher prestige to enterprises and utilizing the signal effect of executives. Taking these expectations together, we proposed the following:

Hypothesis 2a: There is a positive relationship between TMT overseas social capital and prestige.

An enterprise gains knowledge power in an innovation network through its knowledge resources (Latiff and Hassan 2008) and impacts the behavior of other enterprises in the network particularly (Rajan and Zingales 1997). Enterprises which hire executives with overseas work experience are able to obtain not only their information and knowledge about the latest technology, but also insight from different perspectives for innovation. The knowledge power generated by fundamental knowledge and technology resources will enable enterprises to influence and control other enterprises' strategic choices and behavioral decisions in the innovation network (Xu et al. 2014). When executives have high-level professional expertise, knowledge power could be transmitted to the corporate level owing to the key role executives play in the process of corporate operations, so that these firms gain capability in the field of innovation. Moreover, these executives' information and knowledge are updated continuously via their weak ties with global networks which can reduce cognitive rigidity through receiving a variety of information.

At the same time, executives with overseas social capital also provide technology resources to enterprises via ties with foreign technical staff, such as advanced technology introduced. Thus, the enterprises hiring those executives can acquire a louder voice, higher status and superior network power through the transmission of knowledge power and the access to information and technical resources. This situation further enhances an enterprise's control over network resources and information, and consolidates its advantageous network position. So, executives' overseas social capital can promote enterprises' power. Taking these expectations together, we propose the following:

Hypothesis 2b: There is a positive relationship between TMT overseas social capital and power. 
The mediating role of network position

The competition pattern of enterprises has undergone a revolutionary change from pure competition to the coexistence of competition and cooperation, so that a network among enterprises is gradually emerging. Innovation depends on network-based cooperation since there is no enterprise which has all the resources needed for development and innovation. Industry's technological development prospects and changes determine the direction of innovation, while the ability to absorb resources and information depends on the network position of the enterprise (Coleman 2000). External social capital resources are embedded in interrelated social networks of individuals, groups and nations, and thus can be accessed through social networks (Bolino and Turnley 2002; Inkpen and Tsang 2005). Existing research demonstrates that corporate external social capital has a positive effect on innovation via knowledge spillover, learning effect (Wang 2013), the recognition of entrepreneurial opportunities (Zhang and Sun 2017) and so on. Corporations occupying good network positions may have more opportunities to contact and obtain external information and diverse resources (Coleman 2000) and therefore have a better innovation performance.

According to social stratification, social prestige is a scarce resource distributed unevenly in networks (Ling 2009). At the individual level, a person's prestige reflects his or her popularity and individuals who have higher prestige may acquire more positive choices (Ling 2009). At the organizational level, we define the corporate network prestige as recognition and evaluation the corporate obtains from the rest of the network. Hence, we infer that corporations engaged in the network will prefer to cooperate with those with higher prestige. High-prestige corporations will tend to collaborate and achieve innovative success since innovation is risky and resource-consuming and thus requires combined efforts of enterprises (Zhu et al. 2017). Besides, an enterprise will obtain more information and resources from external elements due to high prestige or popularity, and then boost its communication with others. Communication will enhance the cooperation efficiency among enterprises, and the success of innovation will be further improved. According to resource-based theory, access to cooperation and practical information are different resources the enterprise has that can improve its innovation. Taking these expectations together, we propose the following:

\section{Hypothesis 3a: Prestige mediates the relationship between TMT overseas social capital and innovation.}

Enterprise network power, generated by the asymmetry of resource dependence in the network, refers to the ability of an enterprise to influence and control the strategic choice and behavior decision of other members in the process of network exchange in order to realize its own aspirations or meet its own interest demands (Olsen et al. 2014). Enterprises which obtain greater power can seize more opportunities to implement controls on others in the network in order to pursue their targets, because they can influence or even control other enterprises' behaviors due to control interest (Burt 2009). In other words, enterprises with greater power can gain higher profits when cooperating with other interlocking enterprises due to their control. Moreover, enterprises with high power status are often facilitated to explore and acquire knowledge resources, thus shortening the time of developing new skills and new knowledge, and quickly 
integrating with the changing market (Maloni and Benton 2000). According to the resource-based view, enterprises' innovation depends on the resources they can receive from internal and external sources. Therefore, the power given by executives' overseas social capital becomes a pivotal factor in obtaining and controlling resources, including information, for enterprises.

Thus, an enterprise can benefit from cooperation with other enterprises and access more useful information for innovation when its power is relatively high. Taking these expectations together, we propose the following:

Hypothesis 3b: Power mediates the relationship between TMT overseas social capital and innovation.

\section{The moderating role of TMT investment bank social capital}

Firms with prestige have a favorable network position, which has a positive effect on organizational innovation (Zhu et al. 2017). Though network position provides value and allows the actors to develop trust to access resources through embedded linkages (Li et al. 2014), innovations also carry risks (Merton 2013). One of the biggest threats in the process of innovation is financing constraints. According to resource-based theory, the resources inside firms are insufficient for a firm's development. Financing constraints occur when capital market imperfections exist (Hottenrott and Peters 2009), thus obtaining a bank's support is especially vital in the imperfect capital market institutional environment in China. TMT's bank social capital, which is a shortcut to break the funding bottleneck, naturally becomes a useful way to remedy capital market imperfections, and is a beneficial solution to financing constraints. In the process of accelerating enterprise human resource management and the innovation process, compensation and incentive mechanisms play a vital role in enterprise human resource management, and are important in the integration and use of corporate social capital. Additionally, they decrease the breakage risk of capital chain from firm prestige to innovation practices. Taking these expectations together, we propose the following:

Hypothesis 4a: TMT bank social capital positively moderates the relationship between prestige and innovation.

The nature of capital is chasing added value. Karl Marx stated, "for the movement, in the course of which it adds surplus-value, is its movement, its expansion, therefore, is automatic expansion" (Marx 1887: p. 94). Although organizational power may lead to various resource channels and promote efficient integration, TMT bank social capital shows the direction and the expansion of capital in the process of innovation projects. TMT bank social capital has access to the information on the newest capital surplus-value and may help enterprises choose the relatively correct direction of investment through market experience and capital appreciation. At the same time, the bank experiences of TMT (or TMT bank social capital) will provide investment choices for the enterprise's high-level management decisions, and guarantee the capital input direction. Taking these expectations together, we proposed the following: 
Hypothesis 4b: TMT bank social capital positively moderates the relationship between power and innovation.

\section{Methodology}

\section{Sample and procedures}

For the detailed TMT social capital information and the firms' specific records of innovation, we focus on the listed companies in Chinese A-share listed companies. According to the China Stock Market and Accounting Research database (CSMAR) and listed companies' annual reports, we have identified the interlocking directors and created the whole network of listed companies from 2008 to 2014. Our data for the analysis is from the CSMAR database, which provides the fundamental background and TMT information of listed-firms in China, the Shanghai Stock Exchange (www.sse.com.cn), the Shenzhen Stock Exchange (www.szse.cn), and the annual report of the listed company for supplements. Finally, we obtain samples of 1476 firms and 5130 firm-years, after deleting the isolated firms, financial firms, and the ST, ZT firms. Table 1 shows the specific description of all variables.

A board interlock can be created between enterprises when one director in one firm joins another firm's board (Burt 1980; Mizruchi 1996). The relationship of interlocking directorates is one way to manage environmental uncertainty, access diverse resources, and communicate across firms (Salancik and Pfeffer 1978). One reason why interlocking directorates escalate is that the connections are a low-cost channel for communication across firms

Table 1 Variables

\begin{tabular}{|c|c|c|c|}
\hline Variable & Symbol & Name of variable & Definition of variable \\
\hline $\begin{array}{l}\text { Dependent } \\
\text { variable }\end{array}$ & INNOVATION & $\begin{array}{l}\text { Innovation ability of } \\
\text { the enterprise }\end{array}$ & $\begin{array}{l}\text { Natural logarithm of the number of patents in the } \\
\text { enterprise at year } t+2\end{array}$ \\
\hline $\begin{array}{l}\text { Independent } \\
\text { variable }\end{array}$ & OVERSEA_C & $\begin{array}{l}\text { Executives' overseas } \\
\text { social capital }\end{array}$ & $\begin{array}{l}\text { Total number of people in the executive team who have } \\
\text { overseas working experience at year } t\end{array}$ \\
\hline \multirow[t]{2}{*}{$\begin{array}{l}\text { Mediate } \\
\text { variable }\end{array}$} & POWER & Power in network & $\begin{array}{l}\text { The structural hole in the enterprise's network at year } t+ \\
1\end{array}$ \\
\hline & PRESTIGE & Prestige in network & The centrality of the enterprise's network at year $t+1$ \\
\hline $\begin{array}{l}\text { Moderate } \\
\text { variable }\end{array}$ & BANK_C & $\begin{array}{l}\text { Executives' } \\
\text { investment bank } \\
\text { social capital }\end{array}$ & $\begin{array}{l}\text { Total number of members in executive team who have } \\
\text { investment bank working experience at year } t\end{array}$ \\
\hline \multirow[t]{8}{*}{$\begin{array}{l}\text { Control } \\
\text { variable }\end{array}$} & INNOVATION_I & $\begin{array}{l}\text { Investment in } \\
\text { innovation }\end{array}$ & Natural logarithm of the R\&D investment at year $t$ \\
\hline & SCALE & $\begin{array}{l}\text { Scale of the } \\
\text { enterprise }\end{array}$ & Natural logarithm of the number of employees at year $t$ \\
\hline & $A G E$ & Age of the enterprise & Length of time from the founding year to the year $t$ \\
\hline & SOE & $\begin{array}{l}\text { Nature of actual } \\
\text { controller }\end{array}$ & $\begin{array}{l}\text { Dummy variable, the variable values } 1 \text { when the actual } \\
\text { controller is state-owned enterprise, otherwise the vari- } \\
\text { able values } 0\end{array}$ \\
\hline & DUAL & Dual & $\begin{array}{l}\text { Dummy variable, the variable values } 1 \text { when a person is } \\
\text { both the chairman of the board and the general } \\
\text { manager at year } t \text {, otherwise values } 0\end{array}$ \\
\hline & $B O A R D$ & Board scale & Board scale of the enterprise at year $t$ \\
\hline & IND & Industry & $\begin{array}{l}\text { Dummy variable, set up to refer to } 2001 \text { SFC industry } \\
\text { classification }\end{array}$ \\
\hline & YEAR & Year & The year that the datum was collected \\
\hline
\end{tabular}


(Haunschild 1993). Also, extending research finds board interlocks can be considered "as a conduit to disseminate ideas and innovations" (Galaskiewicz and Wasserman 1989: p. 456). Thus, in our study, we use interlocking directorates to construct the listed-firm network.

\section{Operationalization of variables Innovation}

Following Yu and Liu (2013), we use the patent data from the Wind database, three kinds of patents (i.e., patent of invention, patent for utility models, and appearance design) to sum innovation total ability according to the $0.5,0.3,0.2$ ratios for the above patents' categories separately, and then obtain the innovation total ability index through logarithmic conversion. We also use the simple sum of the three patents (provided in Table 2) in a robustness test by exchanging calculation formula of innovation capability index.

\section{Prestige}

Degree prestige, proximity prestige, and status or rank prestige are three kinds of prestige evaluation. Following Ma and Li (2011) and Zhu et al. (2017), we use degree prestige as the measurement of the relationship between the specific actor and the others. Using software UCINET6.0, we directly measure the connections of the enterprise to stand for the prestige of the enterprise. The method of calculation is as follows:

$$
P E R=\sum_{i=1}^{n} a\left(p_{i}, p_{k}\right)
$$

If there is one board director shared by two firms, the two firms have a connection. Then $a\left(p_{i}, p_{k}\right)=1$,else $a\left(p_{i}, p_{k}\right)=0$.

\section{Power}

The network position as a "structural hole" in a loose network may bring a control advantage to firms (Burt 2009). The theoretical contribution of Burt (2009) lies in the idea that "entrepreneurs bridging structural holes have economic benefits even if the bridge is weak" (Coulon 2005). The higher the score is, the more control and bridging role exists in the network. Power is then generated by the dependence of other enterprises around them. Using software UCINET6.0, we measure power by effective size, which means the size of the actor's network subtracts the redundancy from the network (Zhu et al. 2017). The method of calculation is as follows:

$$
P W R=\sum_{i}\left(1-\sum_{q} P_{i q} m_{j q}\right), q \neq i, j .
$$

Effect size stands for power because it is based on ego-network size minus redundancy. A larger effective size indicates more control power. $j$ stands for all the actors connected with the focal actor, $q$ stands for the third actor besides $i . P_{i q} m_{j q}$ represents the redundancy between focal actor and $j . m_{j q}$ is the strength of the relationship between $j$ and $q$; it equals the ratio of the relationship between $j$ and $q$ divided by the maximum value of $j$ to other actors. $P_{i q} m_{j q}$ means the ratio of the relationship between $i$ and $j$ divided by the relationship between $i$ and other actors. Our overall model is shown in (Fig. 1). 


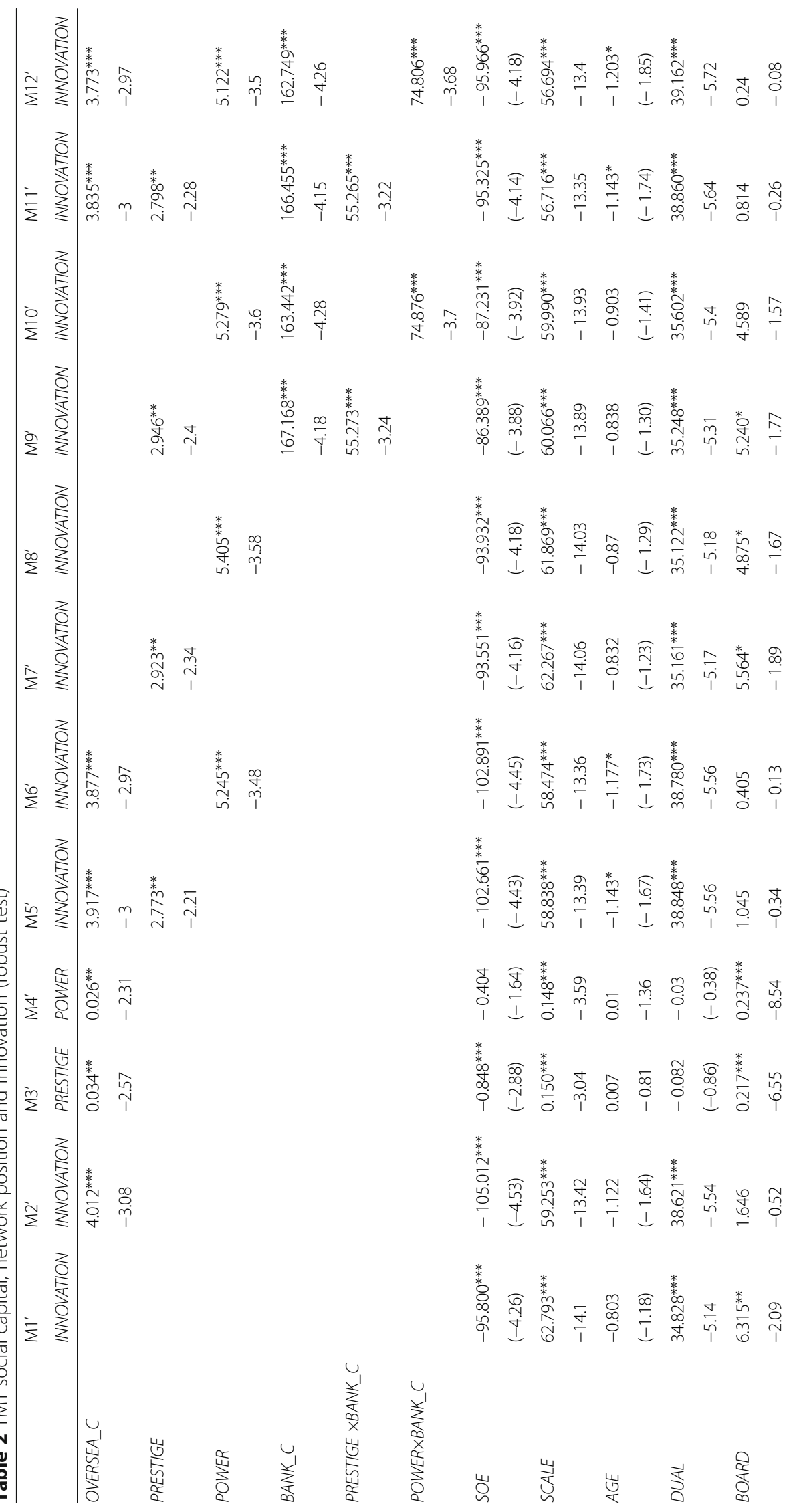




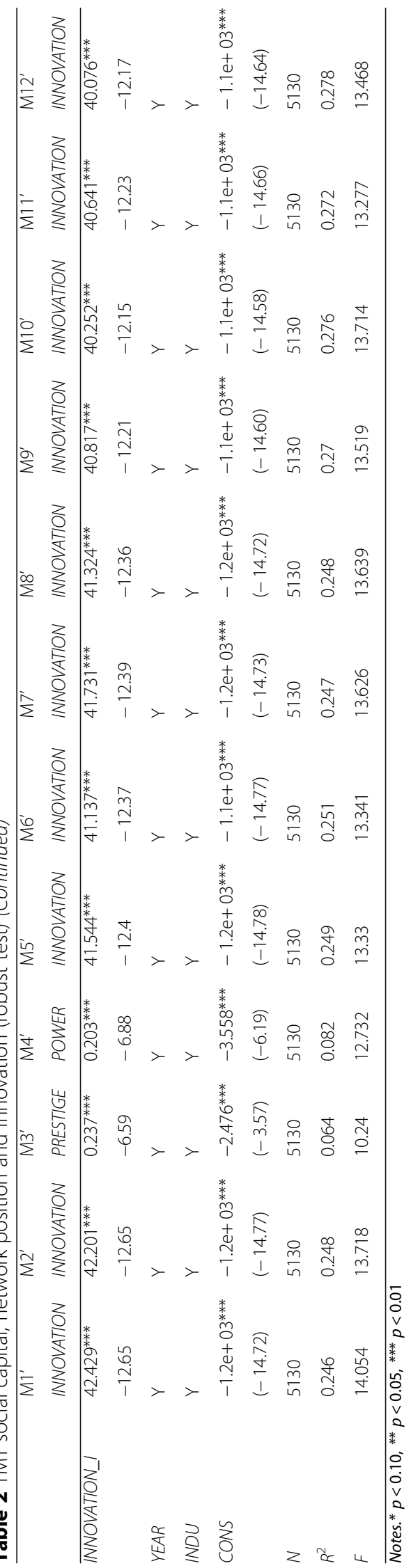




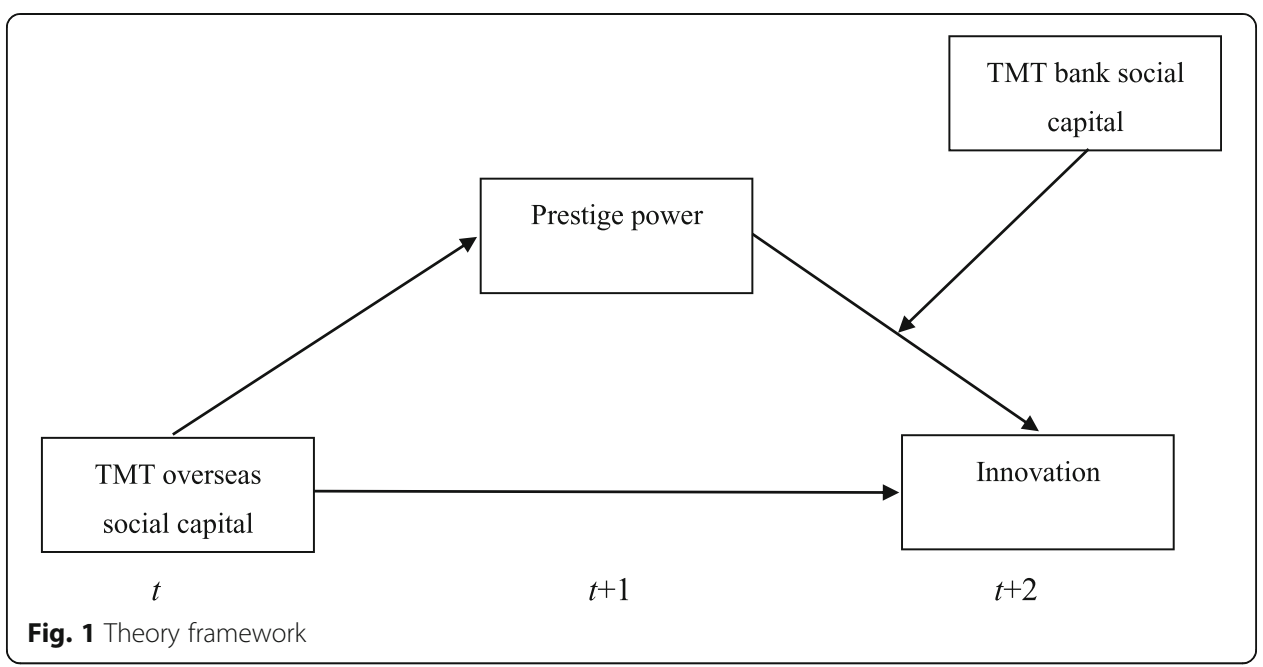

\section{Results}

Descriptive statistics for all variables and correlations among them are presented in Table 1. We use hierarchical multiple regressions to test the hypotheses.

In the analyses, we enter $R \& D$ investment as a control variable to avoid funds' impact on innovation. We also input enterprise size and age (Xu et al. 2014), board scale and the nature of the actual controller (Zhang 2013; Jia and Zhang 2010) as control variables to preclude enterprise-level influence. Additionally, we control the industry and the year in which the datum was collected. All variables in our regressions are stated in Table 3, and we estimate the VIFs (variance inflation factors) to test the potential threat of colinearity. After analysis, we find that all the variables have VIFs lower than 6, which is below the defined ceiling of 10 (Kleinbaum et al. 1988).

According to the second column M2 in Table 4, after controlling variables of R\&D investment, enterprise size, and age, board scale, the nature of the actual controller, industry and year, we find that overseas social capital is positively related $(\beta=1.30, p<$ 0.01 ) to innovation. Thus, Hypothesis 1 is fully supported. Results in the third column M3 and the fourth column M4 show that prestige $(\beta=0.034, p<0.05)$ and power $(\beta=$ $0.026, p<0.05)$ are positively related with overseas social capital which supports Hypothesis $2 \mathrm{a}$ and Hypothesis $2 \mathrm{~b}$. Condition (a) and Condition (b) for mediation can be supported by Hypothesis 1 and Hypothesis 2.

Table 3 Result of correlation analysis

\begin{tabular}{llllll}
\hline & INNOVATION & OVERSEA_C & PRESTIGE & POWER & BANK_C \\
\hline INNOVATION & 1 & & & \\
OVERSEA_C & $0.167^{* * *}$ & 1 & 1 & & \\
PRESTIGE & $0.126^{* * *}$ & $0.194^{* * *}$ & $0.951^{* * *}$ & 1 & \\
POWER & $0.097^{* * *}$ & $0.175^{* * *}$ & 0.0120 & 0.008 & 1 \\
BANK_C & $0.136^{* * *}$ & $0.044^{* * *}$ & 5.465 & 4.017 & 0.028 \\
MEAN & 107.680 & 17.505 & 3.074 & 2.578 & 0.164 \\
SD & 256.382 & 4.314 & & &
\end{tabular}

Notes. ${ }^{*} p<0.10,{ }^{* *} p<0.05,{ }^{* * *} p<0.01$ 


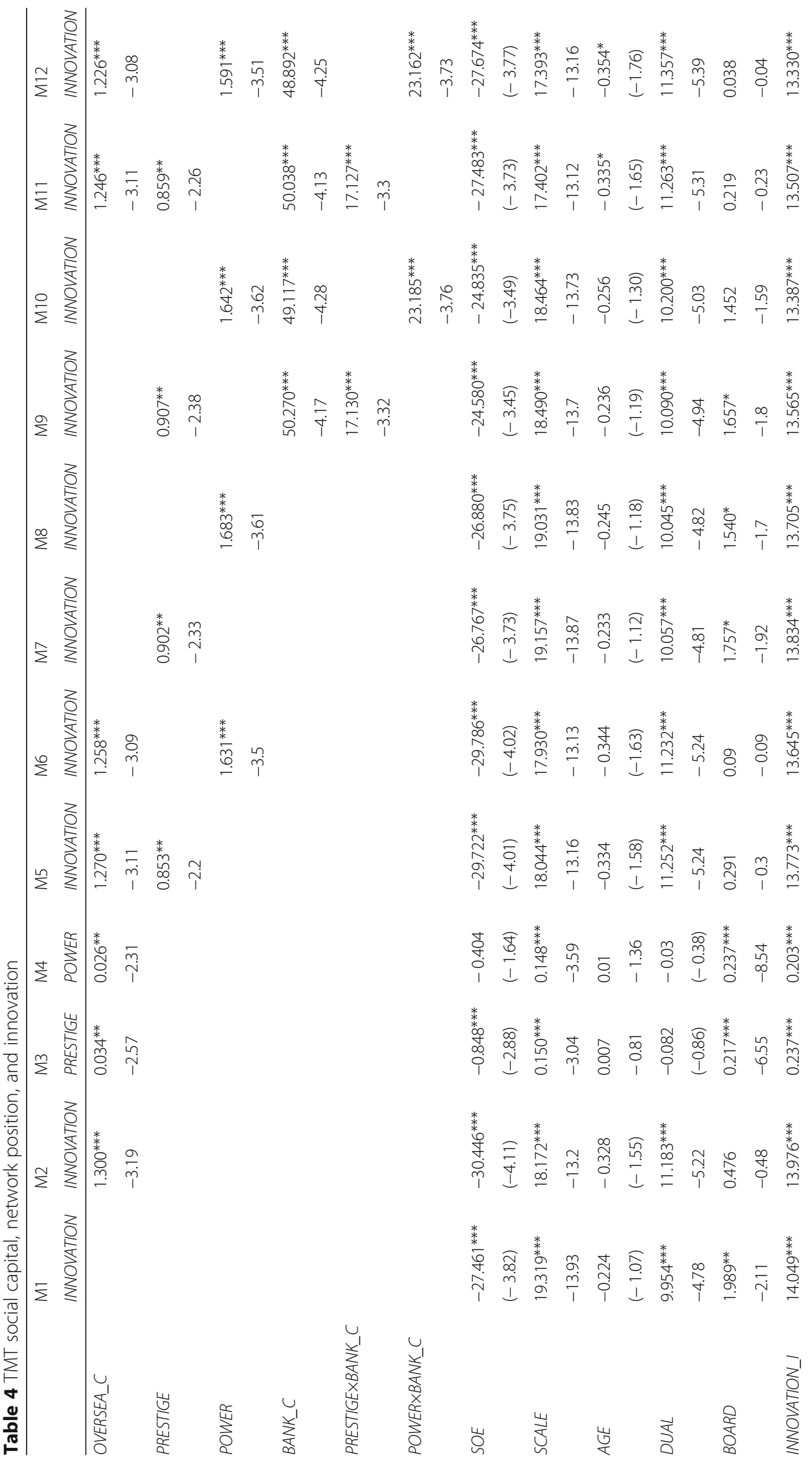




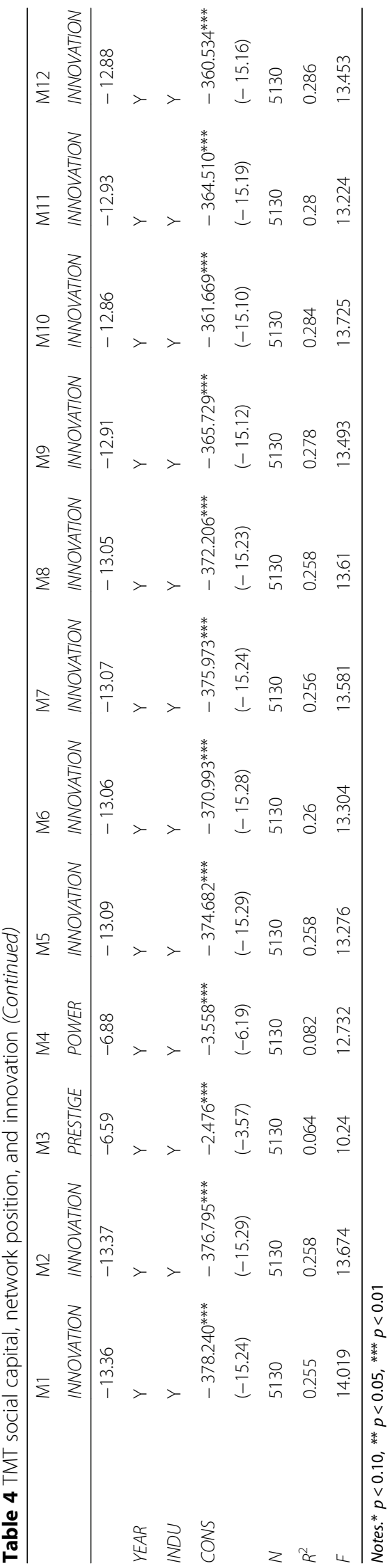


Hypothesis 3 proposes that prestige and power mediate the relationship between overseas social capital and innovation. In a study conducted by Baron and Kenny (1986), there are four essential conditions for establishing mediations: (a) The independent and mediating variables are related considerably; (b)the independent and dependent variables are significantly related; (c) the mediator and dependent variables are significantly related, and (d) the relationship between the independent variables and dependent variables should be insignificant or weaker when the mediator is taken into consideration. Results in the seventh column M7 and the eighth column M8 depict that prestige $(\beta=0.902, p<0.05)$ and power $(\beta=1.683, p<0.01)$ are positively related to innovation, and support Condition (c) for mediation. Further, after prestige and power are considered, the relationship between overseas social capital and innovation is weakened $(\beta=1.270, p<0.01)$, but still significant, which suggests partial mediation. In summary, prestige and power are substantial partial mediators in the model, which supports Hypothesis 3a and Hypothesis $3 \mathrm{~b}$.

To assess moderated mediation (Muller et al. 2005; Preacher et al. 2007), we examine four conditions: (a) significant effects of overseas social capital on innovation; (b) significant interactions between two mediators and investment bank social capital (e.g., prestige and investment bank social capital in predicting innovation has significant interactions); (c) significant effects of prestige and power on innovation; and (d) different conditional effects of prestige and power on innovation across low and high levels of investment bank social capital. The last condition is the essence of moderated mediation, which establishes whether the strength of the mediation differs across the various levels of the moderator (Preacher et al. 2007). Moderated mediation is demonstrated when the conditional indirect effect of prestige and power on innovation differs in strength across low and high levels of investment bank social capital. Results for Hypothesis 1 demonstrate that overseas social capital is significantly related to innovation, and it supports condition (a) for moderated mediation.

We then examine the interaction of prestige and power with investment bank social capital to test for Condition (b) for moderated mediation. Results from Table 3 in the ninth column M9 and the tenth column M10 show that, the interaction terms for investment bank social capital with both prestige $(\beta=17.130, p<0.01)$ and power $(\beta=23.185$, $p<0.01)$ are significant in predicting innovation. Condition (b) for moderated mediation is approved. Condition (c) for moderated mediation is supported by the seventh column M7 and the eighth column M8. Hence, results based on the first three conditions indicate that investment bank social capital might moderate two pairs of relationships: prestige and innovation, and power and innovation. Thus, Hypothesis 4a and Hypothesis $4 \mathrm{~b}$ are supported. Table 3 presents the descriptive statistics to test our hypothesis. The year and industry dummy variables are used and not reported in detail to save space. Table 4 displays the robust test by changing the dependent variables by using the total amount of patent. Similarly, we obtain the same conclusion as formerly.

To further validate findings of moderated mediation relationships, we examine Condition (d) for moderated mediation, which requires the magnitude of the limited effect of the prestige and power to be different for innovation across high and low levels of investment bank social capital. We test moderated mediation separately for each mediator and moderator. We operationalize high and low levels of investment bank social capital as one standard deviation above and below the mean score of the respective job variables. 
Results from Figs. 2 and 3 demonstrate that different levels of investment bank social capital have different moderate effects on two pairs of relationships: prestige and innovation, and power and innovation. The effect of prestige or power on innovation is relatively limited when the investment bank social capital of the top management team is low. That is to say, when the investment bank social capital is low, an enterprise's innovation is not very active regardless of prestige and power. Prestige and power become vital factors of innovation when the investment bank social capital of the top management team is high, which means prestige or power has a great effect on innovation (Wu and Li 2014). Thus Condition (d) for moderated mediation is satisfied. Our results are also supported by using Tobit model, thus there is no censoring bias issue.

We use the method from Preacher et al. (2007) to analyze the moderated mediation. The results are shown in Table 5. The index of moderated mediation when prestige functions as mediator is significant (estimate $=0.61$, CI 0.95 [0.1669, 1.4063], sample size $=10,000)$. Specifically, TMT overseas social capital has a stronger indirect effect (through prestige) on innovation for those who have higher levels of bank capital (indirect effect $=0.62$, CI $0.95[0.1729,1.4225])$, while the indirect effect of those who have lower levels of bank capital (indirect effect $=0.01$, CI $0.95[-0.0089,0.0505]$ ) is not significant; the strength of the indirect relation differ significantly depending on bank capital levels, providing a moderated role of bank capital on the indirect effect of TMT overseas social capital on innovation via prestige.

Additionally, results reveal that the moderated effect of bank capital on the indirect effect through power is also significant (estimate $=0.61$, CI 0.95 [0.1399 1.4202], sample size $=10,000$ ). TMT overseas social capital have a stronger indirect effect (through prestige) on innovation for those who have higher levels of bank capital (indirect effect $=0.64, \mathrm{CI} 0.95[0.1415,1.4536])$ than for those who have lower levels of bank capital (indirect effect $=0.02, \mathrm{CI} 0.95[0.0007,0.0650]$ ), thus supporting the moderating role of bank capital regarding the indirect effect via power.

\section{Discussions and implications}

How is micro social capital transformed into macro social capital and what is their combined effect on organizational innovation? This study uses the micro TMT

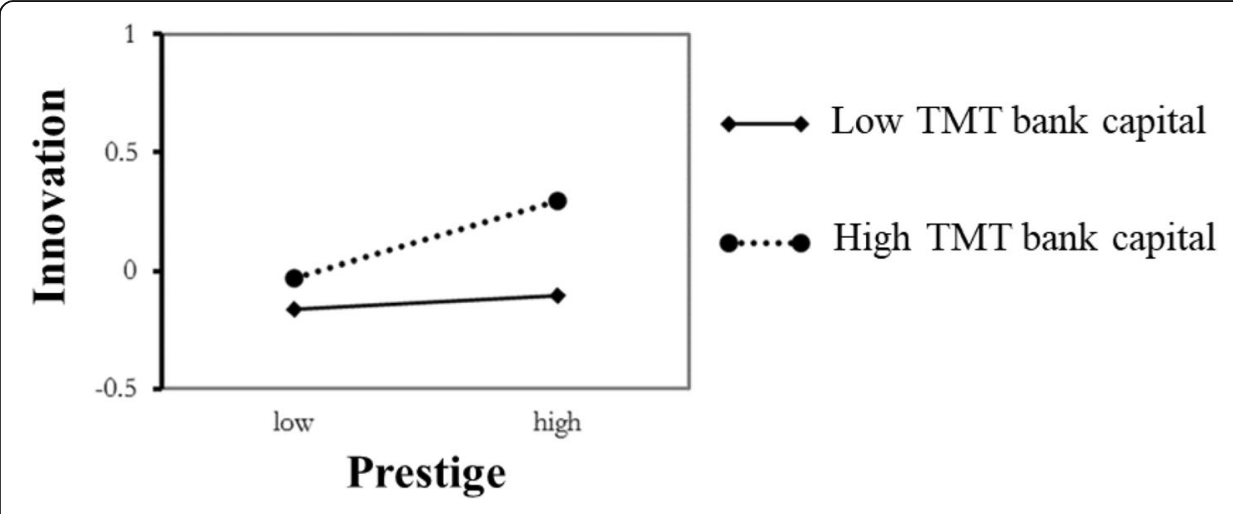

Fig. 2 TMT investment bank social capital moderates the relation between prestige and innovation 


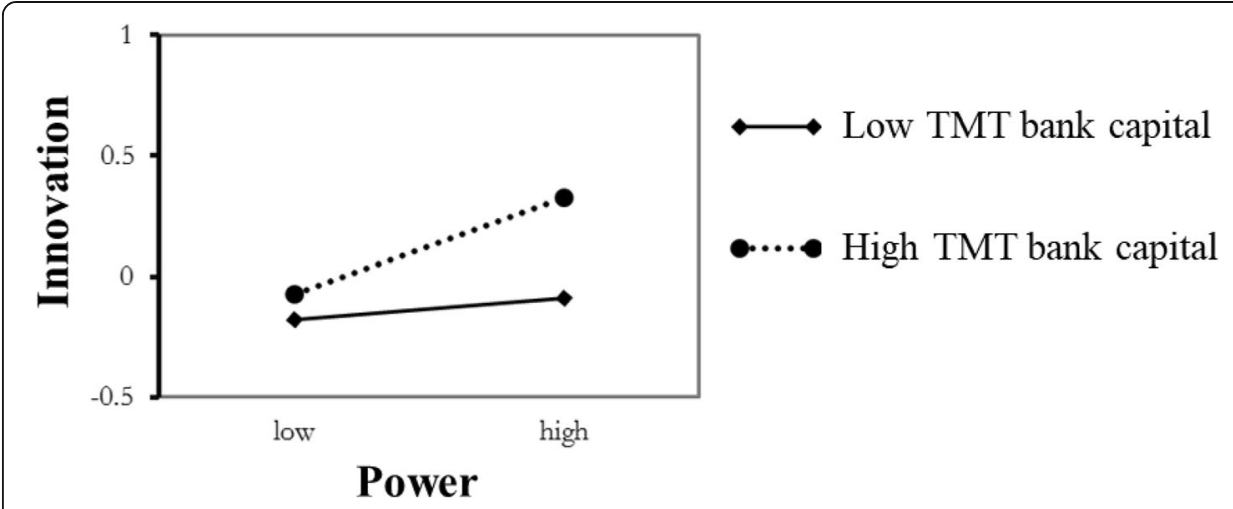

Fig. 3 TMT investment bank social capital moderates the relation between power and innovation

overseas social capital, bank social capital and macro advantage network position together to answer the question critically.

Social capital is the bedrock of innovative capabilities (Subramaniam and Youndt 2005); as an extension of the resource-based view, we focus on the social capital aspect since it is embedded in external linkages (Li et al. 2014). In our study, we conclude that a firm's innovation is significantly increased by TMT overseas social capital. By developing links between international talents and bridging relationships between international elites and companies, the TMT bonds cutting-edge international technologies to explore future directions of enterprise development and innovation. We specify the mechanism of bridging and bonding effects through extending the present result of TMT's social capital.

Embedded in the network, these relationships may influence a firm's R\&D and innovation opportunities (Granovetter 1985). Influence and control are correlations with the advantages of network position (Burt 2009), while little prior research has quantitatively measured the role of macro advantage network position in the process of micro social capital's macro transformation to the organization level. The result of our research shows that the organizational advantage network has a bonding effect on the micro TMT social capital and organizational innovation. Firms occupying an advantageous network location bond an individual's prestige and trustworthiness in the process of communication and cooperation by using the influence of prestige. Moreover, the person with power, through whom the source's network is embedded, bonds and

Table 5 Test of moderated mediation

\begin{tabular}{|c|c|c|c|}
\hline Moderator & Indirect effect & SE & $\mathrm{Cl} 0.95$ \\
\hline \multicolumn{4}{|l|}{ Prestige as a mediator } \\
\hline Low bank capital & 0.0105 & 0.0142 & {$[-0.0089,0.0505]$} \\
\hline High bank capital & 0.6214 & 0.3033 & {$[0.1729,10.4225]$} \\
\hline Difference & 0.6108 & 0.3004 & {$[0.1669,10.4063]$} \\
\hline \multicolumn{4}{|l|}{ Power as a mediator } \\
\hline Low bank capital & 0.0208 & 0.0154 & {$[0.0007,0.0650]$} \\
\hline High bank capital & 0.6352 & 0.3183 & {$[0.1415,10.4536]$} \\
\hline Difference & 0.6144 & 0.3114 & {$\left[\begin{array}{lll}0.1399 & 10.4202\end{array}\right]$} \\
\hline
\end{tabular}


bridges the innovative ideas and technologies by highly efficient utilization, high resource integration, and control capability.

This research also demonstrates that the interaction between organizational network position and TMT bank social capital affects a firm's innovation. This finding is useful for previous research which examines the combined effects, though there is no effective means of quantifying prestige and power. A central actor may access knowledge network links (Tsai 2001) and promote firms to reduce environmental uncertainties (Tian and Yan 2013). We have extended the elements of resources and cost to bonding micro TMT social capital and the transformation process to organizational innovation. The capital and experience positively moderate the relationship between prestige and innovation by decreasing the capital risk and the possibility of capital chain breakage. Furthermore, TMT bank social capital may help guarantee the capital input direction and provide investment choices by familiarity with the nature of capital and the investment experience.

In conclusion, this study contributes to existing research in the following aspects. First, this study reveals the possible path of transformation of micro social capital to macro social capital. It enhances our understanding of how firms use the social capital of TMT and organizational network position to improve their innovation by exploring the nature of micro-macro links. Based on the data of 5130 listed firms in China, our results contribute to the understanding of the combined effect of micro and macro social capital in TMT and organizational level respectively. The study shows that TMT overseas social capital is positively associated with corporate innovation and that the organizational network position partially mediates the effect of TMT overseas social capital and innovation. Moreover, TMT bank social capital moderates the relationship between organizational network position and innovation. Our research then provides empirical support to understand the relationship between micro TMT social capital, macro network position, and innovation. By offering both micro and macro measurements of TMT social capital and by testing two dimensions of social capital, we contribute to both theoretical and empirical development of the typical stream of research on innovation. Second, our research links micro and macro social capital together to explain the innovation process to extend the resource-based theory in innovation area research. We also attempt to make a meaningful quantitative study to explore the nature of bonding and bridging mechanisms. Third, we link TMT social capital with the organizational network position as an explanation of firm-level advantage networking ability, thus assisting human resource management in the TMT level selection. At the same time, the enterprise should pay more attention to the TMT social capital to obtain more efficient and low-cost access to precious resources needed for the firm's innovation. Furthermore, a suitable salary incentive mechanism should be established to stimulate bonding and bridging to efficiently utilize existing social capital at both micro and macro levels.

\section{Limitations and future research direction}

The limitations of our research offer more opportunities for future examination. First, although we are fully confident that our findings can be generalized to the listed firm in the whole interlocking directorate network in China, we are not reasonably sure whether the conclusion can be generalized to isolated actors (listed firms) and non-listed firms. The former category, i.e., isolated firms, have no ties with other firm and belong to an entirely different mechanism because they have no imprint in the 
interlocking directorate network. As for the latter category, i.e., non-listed firms, they have a completely different operating and management environment. Although our empirical analysis does not systematically contain all the types of firms for the data limitation, it undermines no referential significance of conclusions. Future researchers may examine different samples and measurements to construct the listed-firm network.

Second, we firmly believe that our findings focusing on TMT should not be biased for the accounting differences. The conceptualization of power and prestige are differentiated network positions and highlights the differences between listed firms in the whole interlocking directorate network. We calculate the network position using social network analysis, which has been compiled into an interlocking directorate dimension measure for simplified measurement purposes.

Third, the last limitation of this research is that we ignore the potential impact of firm innovation on TMT social capital. "The level of casual analysis adopted in the embeddedness argument is a rather proximate one" (Granovetter 1985: p. 506); for instance, a highly innovative entity with a promising future may attract elites to enter TMT. Given the inherent causal ambiguity, the combination of social capital and transaction cost theory (Williamson 1985) may help overcome the problem to some degree by identifying and distinguishing the origins of TMT social capital growth.

Acknowledgements

Not Applicable.

Funding

Not applicable.

\section{Availability of data and materials}

For the detail TMT social capital information and the firms' specific records of innovation, we focus on the listed companies in Chinese A-share listed companies. According to China Stock Market \& Accounting Research Database (CSMAR) and listed companies' annual report, we have identified the interlocking directors and created the whole network of listed companies from 2008 to 2014. Our data for the analysis is from CSMAR database, which provides the fundamental background and TMT information of listed-firms in China, Shanghai Stock Exchange (www.sse.com.cn), Shenzhen Stock Exchange (www.szse.cn), and the annual report of the listed company for supplements. We identify interlocking directors by using CSMAR and annual reports of the listed companies to construct the whole network of listed-firms in China from 2008 to 2014. At last, we obtain samples 1476 firms and 5130 firm-years, after deleting the isolated firms, financial firms, and ST, ZT firms.

\section{Authors' contributions}

LZ, LC and YC explored data and YC do the basic data processing. Then LZ and LC operated the model and LZ described samples and methods of this research while GZ reported the data analysis result. GZ and LZ worked together to finish the sections of introduction, theoretical background, hypotheses, discussion and limitation. Finally, YC polished words of this manuscript. All authors read and approved the final manuscript.

Competing interests

The authors declare that they have no competing interests.

\section{Publisher's Note}

Springer Nature remains neutral with regard to jurisdictional claims in published maps and institutional affiliations.

\section{Author details}

${ }^{1}$ Renmin University of China, Beijing, China. ${ }^{2}$ National School of Development, Peking University, Beijing, China.

Received: 8 February 2018 Accepted: 3 January 2019

Published online: 30 January 2019

References

Abrahamson, E., \& Rosenkopf, L. (1997). Social network effects on the extent of innovation diffusion: A computer simulation. Organization Science, 8(3), 289-309.

Ahuja, G. (2000). Collaboration networks, structural holes, and innovation: A longitudinal study. Administrative Science Quarterly, 45(3), 425-455. 
Andersson, U., Forsgren, M., \& Holm, U. (2002). The strategic impact of external networks: Subsidiary performance and competence development in the multinational corporation. Strategic Management Journal, 23(11), 979-996.

Barney, J. (1991). Firm resources and sustained competitive advantage. Advances in Strategic Management, 17(1), 3-10.

Baron, R. M., \& Kenny, D. A. (1986). The moderator-mediator variable distinction in social psychological research: Conceptual, strategic, and statistical considerations. Journal of Personality and Social Psychology, 51, 1173-1182.

Bolino, M. C., \& Turnley, W. H. (2002). Citizenship behavior and the creation of social capital in organizations. Academy of Management Review, 27(4), 505-522.

Bourdieu, P. (1986). The forms of capital. In Handbook of theory \& research of for the sociology of education (pp. 280-291).

Bourdieu, P., \& Wacquant, L. J. D. (1992). An invitation to reflexive sociology. University of Chicago Press (pp. 20-53).

Burt, R. S. (1980). Cooperative corporate actor networks: a reconsideration of interlocking directorates involving American manufacturing. Administrative Science Quarterly, 25(4), 557-582.

Burt, R. S. (2009). Structural holes: the social structure of competition (pp. 23-100). Harvard University Press.

Cho, Y., Hwang, J., \& Lee, D. (2012). Identification of effective opinion leaders in the diffusion of technological innovation: a social network approach. Technological Forecasting and Social Change, 79(1), 97-106.

Coleman, J. (1990). Foundations of social theory (pp 55-78). Belknap Press of Harvard University Press

Coleman, J. S. (2000). Chapter 2 - Social Capital in the Creation of Human Capital. Knowledge and Social Capital: Foundations and Applications.

Coulon, F. (2005). The use of social network analysis in innovation research: a literature review (pp 78-100). Lund University

de la Tour, A., Glachant, M., \& Ménière, Y. (2011). Innovation and international technology transfer: the case of the Chinese photovoltaic industry. Energy Policy, 39(2), 761-770.

Dyer, J. H., \& Singh, H. (1998). The relational view: cooperative strategy and sources of inter-organizational competitive advantage. Academy of Management Review, 23(4), 660-679.

Finkelstein, S., Hambrick, D. C., \& Cannella, A. A., Jr. (2009). Strategic leadership: theory and research on executives, top management teams, and boards. New York: Oxford University Press.

Galaskiewicz, J., \& Wasserman, S. (1989). Mimetic processes within an inter-organizational field: an empirical test. Administrative Science Quarterly, 34(3), 454-479.

Geletkanycz, M. A., \& Hambrick, D. C. (1997). The external ties of top executives: Implications for strategic choice and performance. Administrative Science Quarterly, 42(4), 654-681.

Granovetter, M. (1985). Economic action and social structure: the problem of embeddedness. American Journal of Sociology, 91(3), 481-510.

Gulati, R. (1999). Network location and learning: the influence of network resources and firm capabilities on alliance formation. Strategic Management Journal, 20(5), 397-420.

Gulati, R., Nohria, N., \& Zaheer, A. (2000). Strategic networks. Strategic management journal, 21(3), 203-215.

Hambrick, D. C. (2007). Upper echelons theory: an update. Academy of Management Review, 32(2), 334-343.

Hambrick, D. C., \& D'Aveni, R. A. (1992). Top team deterioration as part of the downward spiral of large corporate bankruptcies. Management Science, 38(10), 1445-1466.

Hambrick, D. C., \& Mason, P. A. (1984). Upper echelons: the organization as a reflection of its top managers. Academy of Management Review, 9(2), 193-206.

Haunschild, P. R. (1993). Interorganizational imitation: the impact of interlocks on corporate acquisition activity. Administrative Science Quarterly, 38(4), 564-592.

Helmers, C., Patnam, M., \& Rau, P. R. (2017). Do board interlocks increase innovation? Evidence from a corporate governance reform in India. Journal of Banking \& Finance, 80, 51-70.

Hottenrott, H., \& Peters, B. (2009). Innovative capability and financing constraints for innovation: more money, more innovation? Review of Economics \& Statistics, 94(9-081), 1-40.

Huang, H. (2011). Technological innovation capability creation potential of open innovation: a cross-level analysis in the biotechnology industry. Technology Analysis \& Strategic Management, 23(1), 49-63.

Inkpen, A. C., \& Tsang, E. W. K. (2005). Social capital, networks, and knowledge transfer. Academy of Management Review, 30(1), 146-165.

Jia, M., \& Zhang, Z. (2010). Does political connection influence corporate philanthropy? Management World, 4(4), 99-113.

Jianwen, W., \& Yandong, Z. (2011). Power or prestige? The debates and verifications in measurement of social capital. Sociological Studies, 3, 005.

Jing, Z., Wang, M., Limin, \& Ding. (2014). Corporate social capital and business model innovation: The mediating role of organizational learning. Frontiers of Business Research in China, 8(4), 500-528.

Johnson, \& Phyllis. (1998). A study of cognition and behavior in top management team interaction (pp. 101-150). Cranfield University

Jokinen, T., Brewster, C., \& Suutari, V. (2008). Career capital during international work experiences: Contrasting self-initiated expatriate experiences and assigned expatriation. International Journal of Human Resource Management, 19(6), 979-998.

Keister, L. A., \& Lu, J. (2001). The transformation continues: The status of Chinese state-owned enterprises at the start of the Millennium (Vol. 12). (pp 23-50). National Bureau of Asian Research: .

Kleinbaum, D. G., Kupper, L. L., \& Muller, K. E. (1988). Applied regression analysis and other multivariable methods. Boston: PWS Publishing.

Landry, R., Amara, N., \& Lamari, M. (2002). Does social capital determine innovation? To what extent? Technological Forecasting and Social Change, 69(7), 681-701.

Lane, P. J., \& Lubatkin, M. (1998). Relative absorptive capacity and inter-organizational learning. Strategic Management Journal, 19(5), 461-477.

Latiff, H. S. B. H. N. M. A., \& Hassan, A. (2008). Rise and fall of knowledge power: an in-depth investigation. Humanomics the International Journal of Systems \& Ethics, 24(1), 17-27.

Lawson, B., Tyler, B. B., \& Cousins, P. D. (2008). Antecedents and consequences of social capital on buyer performance improvement. Journal of Operations Management, 26(3), 446-460.

Leibold, M., Probst, G. J., \& Gibbert, M. (2007). Strategic management in the knowledge economy: new approaches and business applications (pp 78-120). Wiley.

Levin, H., Meyer, J. W., \& Scott, W. R. (1985). Organizational environments: ritual and rationality. Administrative Science Quarterly, 3(4). 
Li, C. (2005). Prestige stratification in the contemporary Cchina: occupational prestige measures and socio-economic index. Sociological Research.

Li, C. R., Lin, C. J., \& Huang, H. C. (2014). Top management team social capital, exploration-based innovation, and exploitationbased innovation in smeSMEss. Technology Analysis \& Strategic Management, 26(1), 69-85.

Lin, N. (2002). Social capital: a theory of social structure and action (Vol. 19) (pp 55-85). Cambridge University Press.

Lin, N. (2008). A network theory of social capital. The Handbook of Social Capital, 50(1), 69.

Lin, N., Cook, K. S., \& Burt, R. S. (2001). Social capital: theory and research. Aldine transaction.

Ling, J. R. (2009). Social network analysis: theory, method and application.

Luo, Y., \& Chen, M. (1997). Does guanxi influence firm performance? Asia Pacific Journal of Management, 14(1), 1-16.

Ma, F. P., \& Li, Y. P. (2011). Top managerial social capital, resource acquisition and technological innovation performance in resource-based enterprises. Economic Management Journal, 8.

Maloni, M., \& Benton, W. C. (2000). Power influences in the supply chain. Journal of Business Logistics, 21(1), 49-74.

Marx, K. (1887). Capital (pp 322-350). Progress Publishers.

Merton, R. C. (2013). Innovation risk. Harvard Business Review, 91(4), 48-56.

Michel, J. G., \& Hambrick, D. C. (1992). Diversification posture and top management team characteristics. Academy of Management Journal, 35(1), 9-37.

Mizruchi, M. S. (1996). What do interlocks do? An analysis, critique, and assessment of research on interlocking directorates. Annual Review of Sociology, 22(1), 271-298.

Muller, D., Judd, C. M., \& Yzerbyt, V. Y. (2005). When moderation is mediated, and mediation is moderated. Journal of Personality \& Social Psychology, 89(6), 852.

Nahapiet, J., \& Ghoshal, S. (2000). Social capital, intellectual capital, and the organizational advantage. Knowledge and Social Capital, 23(2), 119-157.

Nonaka, I. (2000). A dynamic theory of organizational knowledge creation. In Knowledge, groupware and the internet (pp. 3-42).

Olsen, P. I., Prenkert, F., Hoholm, T., \& Harrison, D. (2014). The dynamics of networked power in a concentrated business network. Journal of Business Research, 67(12), 2579-2589.

Paananen, M. (2009). Exploring the relationships between knowledge sources in the innovation process: Evidence from Finnish innovators. Technology Analysis \& Strategic Management, 21(6), 711-725.

Peng, M. W. (2000). Business strategies in transition economies. Thousand Oaks: Sage.

Peng, M. W., \& Heath, P. S. (1996). The growth of the firm in planned economies in transition: Institutions, organizations, and strategic choice. Academy of Management Review, 21(2), 492-528.

Peng, M. W., \& Luo, Y. (2000). Managerial ties and firm performance in a transition economy: The nature of a micro-macro link. Academy of Management Journal, 43(3), 486-501.

Portes, A. (1998). Social capital: its origins and applications in modern sociology. Annual Review of Sociology, 24(1), 1-24.

Powell, W. W., White, D. R., Koput, K. W., \& Owen-Smith, J. (2005). Network dynamics and field evolution: the growth of interorganizational collaboration in the life sciences. American Journal of Sociology, 110(4), 1132-1205.

Preacher, K. J., Rucker, D. D., \& Hayes, A. F. (2007). Addressing moderated mediation hypotheses: theory, methods, and prescriptions. Multivariate Behavioral Research, 42(1), 185-227.

Putnam, R. (1995). Bowling alone, America's declining of social capital. Journal of Democracy, 6(1), 65-78.

Putnam, R. D. (1993). The prosperous community: social capital and public life. American Prospect, 13(13).

Putnam, R. D., Leonardi, R., \& Nanetti, R. Y. (1993). Social capital and institutional success. Making democracy work: Civic traditions in modern Italy, 163, 185.

Qian, X., Xu, W., \& Li, K. (2010). Do entrepreneurial social networks boost enterprise growth? Evidence from the pearl river delta in China. Frontiers of Business Research in China, 4(3), 498-513.

Rajan, R., \& Zingales, L. (1997). Power in a theory of the firm. Number Working Papers, 113(2), 387-432.

Rowley, T., Behrens, D., \& Krackhardt, D. (2000). Redundant governance structures: An analysis of structural and relational embeddedness in the steel and semiconductor industries. Strategic Management Journal, 21(3), 369-386.

Salancik, G. R., \& Pfeffer, J. (1978). A social information processing approach to job attitudes and task design. Administrative Science Quarterly, 23(2), 224-253.

Savory, C. (2009). Building knowledge translation capability into public-sector innovation processes. Technology Analysis \& Strategic Management, 21(2), 149-171.

Shipilov, A., \& Danis, W. (2006). TMG social capital, strategic choice and firm performance. European Management Journal, 24(1), 16-27.

Smith, K., Smith, K. A., Olian, J., Sims, H., O'Bannon, D., \& Scully, J. (1994). Top management team demography and process: The role of social integration and communication. Administrative Science Quarterly, 39(3), 412-438.

Srinivasan, R., Wuyts, S., \& Mallapragada, G. (2018). Corporate board interlocks and new product introductions. Journal of Marketing A Quarterly Publication of the American Marketing Association, 82(1), 132-147.

Stinchcombe, A. L. (1990). Weak structural data. Contemporary Sociology, 19(3), 380-382.

Subramaniam, M., \& Youndt, M. A. (2005). The influence of intellectual capital on the types of innovative capabilities. Academy of Management Journal, 48(3), 450-463.

Sullivan, B. N., \& Tang, Y. (2013). Which signal to rely on? The impact of the quality of board interlocks and inventive capabilities on research and development alliance formation under uncertainty. Strategic Organization, 11(4), 364-388.

Tian, G., \& Yan, W. (2013). The network of interlocking directorates and firm performance in transition economies: Evidence from China. Journal of Applied Business Research, 29(2), 607.

Tsai, W. (2001). Knowledge transfer in intra-organizational networks: effects of network position and absorptive capacity on business unit innovation and performance. Academy of Management Journal, 44(5), 996-1004.

Tsai, W., \& Ghoshal, S. (1998). Social capital and value creation: the role of intra-firm networks. Academy of Management Journal, 41(4), 464-476.

Uzzi, B. (1996). The sources and consequences of embeddedness for the economic performance of organizations: the network effect. American Sociological Review, 61(4), 674-698.

Walder, A. G. (1989). Factory and manager in an era of reform. The China Quarterly, 118, 242-264.

Walder, A. G. (1991). Workers, managers and the state: the reform era and the political crisis of 1989. China Quarterly, 127(127), 467-492. 
Wang, L. (2013). Relation between External Social Capital and Cluster Enterprise Innovation Performance: The Effect of Knowledge Spillover and Learning Effect. Chinese Journal of Management, 3: 019.

Ward, A. J., \& Feldman, D. C. (2008). Survival of the embedded: expelling and embedding forces on members of the corporate elite. Corporate Governance: An International Review, 16(3), 239-251.

Wei, L., \& Wang, Z. (2002). Empirical study on the relationship between characteristics of tmts and firm performance of Chinese businesses. Nankai Business Review, 5(4), 16-22.

Williamson, O. E. (1985). The economic institution of capitalism. New York: Free.

Wu, S., \& Li, Y. (2014). Is enterprise' alliance network diversity helpful for cooperative innovation? A model of moderated mediator. Nankai Business Review, 17(3), 152-160.

Xu, K., He, Z., Wang, R., Management, S. O, \& University, T. P. (2014). The impacts of knowledge power and structure power on network routine in technology innovation network. Journal of Management Science, 27(5), 24-34.

Yu, Y., \& Liu, D. (2013). The effect of the space outflow of china's regional innovation and the effect of the outflow of value chanins: a study, from the perspective of the innovative value chain, on the model of the panel of multidimentsional space. Management World.

Zhang, H., \& Sun, X. (2017). Research on the influence of entrepreneurs' external social capital on entrepreneurial opportunity recognition: a perspective of network embeddedness. Science of Science \& Management of S \& T, 38(12), 133-147.

Zhu, L., Liu, X., Liu, C., \& Yang, H. (2017). Top managerial social capital, firm network position and innovation capability: the mediating effect of prestige and power from firm network position. Science of Science \& Management of S \& T, 38(6), 94109.

Zhang, Z. (2013). An empirical study on the interactive and inter - temporal influence between corporate social responsibility and corporate financial performance. Accounting Research.

Submit your manuscript to a SpringerOpen ${ }^{\odot}$ journal and benefit from:

- Convenient online submission

- Rigorous peer review

- Open access: articles freely available online

High visibility within the field

- Retaining the copyright to your article

Submit your next manuscript at $\boldsymbol{\nabla}$ springeropen.com 